\title{
Long-term relationship between climate change and nomadic migration in historical China
}

\author{
Qing Pei ${ }^{1}$ and David D. Zhang ${ }^{1}$
}

\begin{abstract}
We investigated the relationship between a 2000-year history of nomadic migration and climate change in historical China. By using updated data and statistical methods, the study solved several unanswered questions from past research about the relationship between climate change and the nomadic migration, especially over the long term and on a large spatial scale. The study used correlation analysis, multiple regression analysis, and Granger causality analysis to quantitatively verify the following causal pathway: climate change $\rightarrow$ nomadic migration $\rightarrow$ conflicts between pastoralists and agriculturalists. In the long term, precipitation was a statistically more influential factor on nomadic migration than temperature in historical China. How climate change affects the migration of nomadic minorities in the long term is theoretically explained based on the Push-Pull model as well as statistical evidence.
\end{abstract}

Key Words: climate change; historical China; nomadic migration; pastoralist-agriculturalist conflict; quantitative analysis

\section{INTRODUCTION}

Climate change and nomadic migration in historical China have been found to be closely related (Fang 1990, Fang and Liu 1992). Archeological evidence shows that early nomadic peoples in Eurasia migrated according to climate changes (Bokovenko 2005). Even today, the human pastoral system needs readjustment under the impact of climate change (Galvin 2009). The nomadic migration in historical China refers to the movements of nomadic people, who were from the steppes of Central Asia, Mongolia, and Eastern Europe and were considered to be barbaric in the past (Bai and Kung 2011). The nomadic people resided in northern China, and their migration, especially southward migrations, threatened the territory of Han people and other minorities (Fang and Liu 1992). Therefore, such nomadic migrations were carefully recorded in the different Chinese historical documents (Ge et al. 1997).

Although the association between climate change and nomadic migration has been revealed in previous studies, some issues pertinent to the relationship remain unresolved. First, it remains unclear whether the linkage between climate change and nomadic migration in historical China is a causal relationship in the long term and on a large spatial scale. Second, given insufficient reliable data on precipitation and temperature in the past, the role of drought and cooling in triggering nomadic migration has not been investigated thoroughly. Third, the influences of nomadic migration on conflicts between pastoralists and agriculturalists in historical China have not been mathematically verified with accurate data sets. Lastly, previous research focused only on the southward migration of nomadic minorities (Fang and Liu 1992). The temporal patterns of northward nomadic migration under climatic impact are still unknown. In addition, although past studies have provided insights, none scientifically proved that, in the long term and on a large spatial scale, climate change caused nomadic migration, which then caused conflicts between pastoralists and agriculturalists in historical China. We quantitatively analyzed these issues for the first time in this study.
Climate change is a major concern around the world because of the risks it poses to human society (IPCC 2007). Even agrarian societies in the past were vulnerable to climate change (Galloway 1986). Climate change is suggested to be the ultimate cause of large-scale social crises in preindustrial societies (Zhang et al 2011a). The close association between climate change and population collapse has also been revealed throughout human history (Zhang et al. 2011b). In addition to the social dimension, the economic development of agrarian society in the past was also determined by climate change in the long term (Pei et al. 2013, 2014).

In the past, a pastoral society was even more easily affected by climate change because it had a lower level of buffering and technological capacity than an agricultural society. A pastoral system, in which free-ranging or grass-fed animals are the principal resources, directly interacts with the ecosystem (Pratt et al. 1997). Therefore, grassland with high climatic vulnerability dominates the spatial and temporal movement of pastoralists in acquiring forage and water (Galvin 2009). In semiarid lands, most of which are located in Asia, reduced rainfall decreased grassland productivity by $40 \%$ to $90 \%$ and increased desertification (Huq et al. 2004). If the climate changed, migration to a place with enough grass and water was the only way for nomadic minorities with limited food resources in historical China to adapt. Although population pressure could also drive migration, population density is always low in pastoral regions of China $(\mathrm{Hu} 1983, \mathrm{Li}$ 2007). Therefore, the relationship between climate change and nomadic migration throughout Chinese history warrants insightful scientific research, particularly with statistical evidence.

Complex interactions between nature and society should be resolved on a large scale (Butlin 1993, MacDonald 1998). As in a previous study (Fang and Liu 1992) on climate change and nomadic migration, the study period was 220 BC to AD 1910, which covers almost all periods of imperial China (Roberts 1997, Keay 2008). Updated and improved paleo-climate and nomadic

\footnotetext{
${ }^{1}$ Department of Geography and International Centre for China Development Study, The University of Hong Kong, Hong Kong
} 
migration records were used to guarantee the reliability of the study. Correlation analysis, multiple regression analysis, and Granger causality analysis (GCA) all were applied to systematically and scientifically explore the long-term relationship between climate change and nomadic migration.

We used quantitative methods to determine our findings. Individual incidents that temporarily distorted the pastoral system and specific cases were not considered in this study. This broad-brush approach, although limited in some ways, suited the purpose of this study, which was to determine the association between climate change and nomadic migration in historical China over the long term and on a large spatial scale.

\section{DATA}

\section{Precipitation}

Given the absence of China-wide paleo-precipitation data, 21 documentary-based single-proxy hydroclimate reconstructions with annual resolution were synthesized from 13 published references (see Section 1, Precipitation Reconstruction, in Appendix 1), spanning more than 500 years to guarantee the reliability of the reconstruction. In China, the spatial and temporal abundance of historical records of weather events provides a good proxy network to detect the centennial variability of large-scale precipitation (Zhang 1998). In addition, we used only documentary data because other proxies, such as tree rings and cave speleothems, contain temperature signals (Dayem et al. 2010, Büntgen et al. 2011). Therefore, the reconstructed precipitation anomaly in the study showed only the record of precipitation in historical China.

We collected various complementary historical data, a large portion of which were descriptive records of droughts and floods. These records were mostly quantified by using a five-level classification method that categorized qualitative descriptions and instrumental observations into five numeric grades, with 5 standing for very dry, 3 for normal, and 1 for very wet. Other studies adopted different intensity scaling schemes, e.g., those with more levels (Chen 1987) or with 0 set as normal (Qian et al. 2003), but the rationale remained the same. To depict changes accurately, our study also included lake surface area variations (Fang 1993) and dust storms (Zhang 1984), which are closely correlated with precipitation (Hui et al. 2013).

A wide range of reconstructions from historical documents were used in this study to reinforce the strength and offset the weakness of each single document and interpretation method. Therefore, our precipitation index was optimal and considered several key factors such as resolution, accuracy, and temporal and geographical coverage.

\section{Temperature}

This study adopted a reconstructed temperature series by Yang et al. (2002) from multiproxies, e.g., ice cores, lake sediment, and so on, throughout China. Temperature was reconstructed based on decadal resolution and covered AD 1 to AD 2000. Although other temperature reconstructions have been done in China (Tan et al. 2003, Yi et al. 2012), they did not cover the entire country. Furthermore, the temperature anomaly observed by Yang et al. (2002) was adopted as a reliable climatic indicator to study the relationship between climate change and social responses in historical China (Zhang et al. 2005, Lee and Zhang 2013).

\section{Nomadic migration}

These data were obtained from the latest chronological table of migrations in China compiled from Zhong Guo Yi Min Shi (The History of Migration in China), which provides migration data from $2100 \mathrm{BC}$ to AD 1950 (Ge et al. 1997). Ge et al.'s book is regarded as the most reliable compilation of and the most systematic work on historical migration records ( $\mathrm{Yu}$ 1998). This book is based on records of ancient Chinese royal historians and scientists from empires of both pastoralists and agriculturalists. A full and detailed picture of nomadic migration can be reproduced based on all the records from the book. We used 928 records of the migration of nomadic minorities, ranging from 220 $\mathrm{BC}$ to AD 1910. The data series of nomadic migration events was calculated at the decadal scale, as was done in a previous study (Fang and Liu 1992).

\section{Conflicts between pastoralists and agriculturalists}

Holistic records of Chinese wars since $1000 \mathrm{BC}$ have been collected from the two volumes of Chinese Military History (Editorial Committee of Chinese Military History 1985). Most of these records elaborate on the duration, involved parties, and locations of battles. During the study period, all 2737 battles that had a precise locality and involved both pastoralists and agriculturalists were recorded. Notably, during the Southern and Northern Dynasties, the records used in the analysis included battles between pastoral minorities and Southern Dynasties established by the Han people, who relied on agricultural production. To maintain consistency with nomadic migration, the number of battles between pastoralists and agriculturalists was also calculated in 10-year intervals.

\section{METHODS AND RESULTS}

To keep most variables related to nomadic migration, the lowest significance level was set as 0.1 . Table 1 shows the results of the correlation analysis. In historical China, nomadic migration was correlated with both precipitation $(-0.260, \mathrm{P}<0.01)$ and temperature $(-0.059, \mathrm{P}<0.05)$. Conflicts between pastoralists and agriculturalists were significantly correlated with nomadic migration $(0.076, \mathrm{P}<0.01)$.

Table 1. Correlation analysis of climate change, nomadic migration, and conflict numbers.

\begin{tabular}{lccc}
\hline \hline & Precipitation & Temperature & $\begin{array}{c}\text { Conflict } \\
\text { number }\end{array}$ \\
\hline Nomadic migration & -0.260 & -0.059 & 0.076 \\
P value & $<0.01$ & $<0.05$ & $<0.01$ \\
\hline
\end{tabular}

Given that both precipitation and temperature can affect nomadic migration, multiple regression analysis was used (Table 2). To address auto-correlation issues in a time series, a flexible time trend $\left(t, t^{2}\right.$, and $\left.t^{3}\right)$ was also considered in the regression analysis (Pei et al. 2013). The temperature data cover AD 1 to AD 1910. Therefore, we implemented multiregression analysis of the effects of precipitation and temperature on nomadic migration from AD 1 to AD 1910. To further compare the contributions of precipitation and temperature at the same level, precipitation and temperature data were normalized before regression analysis. Based on the results in Table 2, the coefficient of precipitation was significant at the 0.01 level and negative, which indicates that 
Table 2. Regression analysis of climate change and nomadic migration.

\begin{tabular}{|c|c|c|c|c|}
\hline & \multicolumn{2}{|c|}{ Estimate } & \multirow[t]{2}{*}{$t$-test } & \multirow[t]{2}{*}{$P$ value } \\
\hline & $\mathrm{B}$ & $\mathrm{SE}$ & & \\
\hline Constant & 5.393 & 0.608 & 8.868 & $<0.01$ \\
\hline Precipitation & -1.068 & 0.101 & -10.618 & $<0.01$ \\
\hline Temperature & -0.092 & 0.107 & -0.856 & 0.392 \\
\hline$t$ & -0.003 & 0.002 & -2.294 & $<0.05$ \\
\hline$t^{2}$ & $3.172 \mathrm{E}-006$ & 0.000 & 3.683 & $<0.01$ \\
\hline$t^{3}$ & $-1.337 \mathrm{E}-019$ & 0.000 & -7.712 & $<0.01$ \\
\hline
\end{tabular}

considerable precipitation reduced the number of nomadic migration events. However, for temperature, the coefficient was not significant even at the 0.1 level.

We then used GCA to validate the time sequence and predictability of the causal relationship between climate change and nomadic migration, and between nomadic migration and conflicts between pastoralists and agriculturalists (See Section 2, Granger Causality Analysis, in Appendix 1). GCA is an effective method of building a causal relationship (Russo 2009). Although GCA does not definitely suggest causality, this method quantitatively supports theoretical analysis with statistical evidence (Zhang et al. 2011a). In addition, statistical laws are considered important in interpreting historical laws based on numerous cases, although statistical laws cannot apply to every single case (Bunge 2009). Through GCA, the causal relationship between variables is confirmed if the cause precedes the effect in time and the causal series contains special information that well explains and forecasts the series that was caused (Granger 1988). Prior to GCA, the Augmented Dickey-Fuller test was used to check the stationarity of the time series. If necessary, differencing was used to transform the time series into stationary time series (Thornton 2001). The lag was set in two ways: the first based on theoretical and empirical knowledge of the relationships, such as an instantaneous cause, and the second on statistical criteria for other relationships (Granger 1988, Saunders 1988). For nearly instantaneous causal linkages, the time lag for GCA was set as 1 (Zhang et al. 2011a). Otherwise, Akaike's information criterion was adopted as the statistical criterion to determine the appropriate lag length (Akaike 1974). Auto-correlation was considered in GCA by setting lag parameters.

When the climate changed, the grassland degraded immediately in response to drought or cooling. With little food storage and low social development in technology, nomadic minorities had to migrate to new places with sufficient grass and water. Therefore, climate change-nomadic migration could be considered as an immediate linkage that is especially true in historical China. However, nomads did not always migrate to the territory of agriculturalists to avoid conflicts between nomadic minorities and farmers caused by competition for land resources (Hussein et al. 1999). In this case, the lag of GCA on nomadic migrationconflicts between pastoralists and agriculturalists was determined by Akaike's information criterion (Tables A 2 and A 3 in Appendix 1). According to GCA results (Table 3), precipitation was the cause of nomadic migration at the significance level of 0.01 , but temperature was not, and nomadic migration was the cause of conflicts between pastoralists and agriculturalists at the significance level of 0.1 .
Table 3. Granger causality analysis of "climate change $\rightarrow$ nomadic migration $\rightarrow$ conflicts between pastoralists and agriculturalists."

\begin{tabular}{lcc}
\hline \hline Null hypothesis & F-Statistic & P value \\
\hline $\begin{array}{l}\text { Precipitation does not (Granger) cause } \\
\text { nomadic migration. }\end{array}$ & 35.686 & $\mathrm{p}<0.01$ \\
$\begin{array}{l}\text { Temperature does not (Granger) cause } \\
\text { nomadic migration. }\end{array}$ & 0.642 & 0.423 \\
$\begin{array}{l}\text { Nomadic migration does not (Granger) } \\
\text { cause conflict number. }\end{array}$ & 1.471 & $\mathrm{p}<0.1$ \\
$\begin{array}{l}\text { Conflict number does not (Granger) cause } \\
\text { nomadic migration. }\end{array}$ & 1.235 & 0.195 \\
\hline
\end{tabular}

\section{DISCUSSION}

Causal relationship between climate change and nomadic migration in historical China

Figure 1 lists the data curves of precipitation, temperature, and nomadic migration. The figure shows that most nomadic migration peaks were accompanied by little rainfall, low temperature, or both. Furthermore, the climate change-nomadic migration relationship in historical China was verified by different statistical methods over the long term and on a large spatial scale (Tables 1-3). In contrast to mainly qualitative discussion (Fang and Liu 1992) and archaeological case studies (Bokovenko 2005), this study used correlation analysis, multiple regression analysis, and GCA to quantitatively confirm that climate change has been a significant factor in nomadic migration during the past 2000 years in China. Moreover, we also have discussed the relationship between climate change and nomadic migration based on a review of the literature.

\section{Role of precipitation and temperature in triggering nomadic migration in historical China}

Analysis results in Tables 1-3 show that the role of precipitation in triggering nomadic migration in historical China was more significant than that of temperature. The results for precipitation and nomadic migration were significant in all three tests. However, the relationship between temperature and nomadic migration was statistically significant only in the correlation analysis. Notably, precipitation was more important than temperature only over the long term and on a large spatial scale, based on the results of quantitative analysis. 
Fig. 1. A) Precipitation anomaly (mm), 220 BC to AD 1910; B) Temperature anomaly $\left({ }^{\circ} \mathrm{C}\right), \mathrm{AD} 1$ to $\mathrm{AD} 1910$; and C) Nomadic migration, $220 \mathrm{BC}$ to AD 1910.

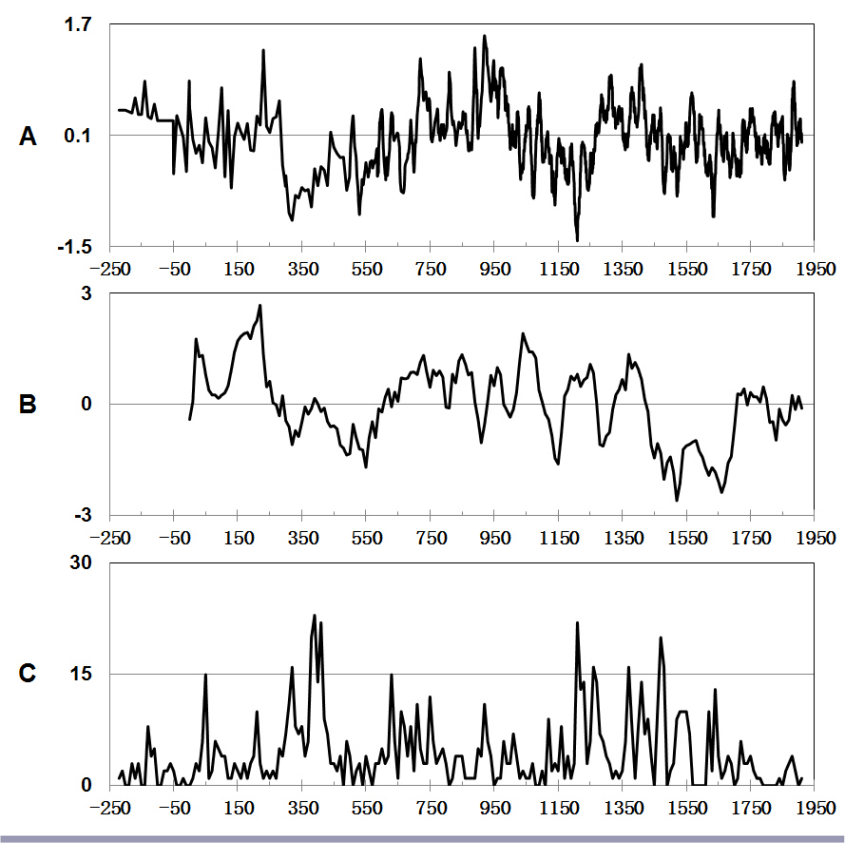

With close scrutiny of nomadic migration, northern China is the traditional area for pastoral minorities. Based on general zoning of Chinese agricultural geography (Zhao 1986, Ren 1999), the pastoral, wheat, and rice regions in China are set as shown in Figure 2. Pastoral China usually covers the semiarid/arid and plateau areas. The bioproductivity of pastoral China is primarily controlled by precipitation (Begzsurena et al. 2004, Sternberg 2008). Given that nomadic minorities resided in northern China in the past, precipitation is more important than temperature. Precipitation is also regarded as a key factor for the pastoral system in the horn of Africa (Meier et al. 2007).

However, our findings are reliable only in the long term. Scale has emerged as a major methodological issue in geography when investigating complex interactions within and among social and natural processes (Sayre 2005). Each scale brings new problems and information coinciding with a new nature or social interface. In the Yuan Dynasty and Qing Dynasty, nomadic minorities controlled the entirety of China, including wheat-producing and rice-producing zones in China. Despite this, these two dynasties were short lived compared with the whole study period; this short period (Yuan Dynasty and Qing Dynasty) accounts for only $20 \%$ of the length of the study period. Therefore, in the long-term study scale, precipitation had a greater influence on nomadic migration than temperature. However, the temperature still showed its significant impacts on nomadic migration according to the results of correlation analysis (Table 1). In addition, the study does not deny the importance of cooling in driving nomadic migration in the short term or in other case-based research.
Fig. 2. Pastoral zone and agricultural zone (wheat zone and rice zone) in China.

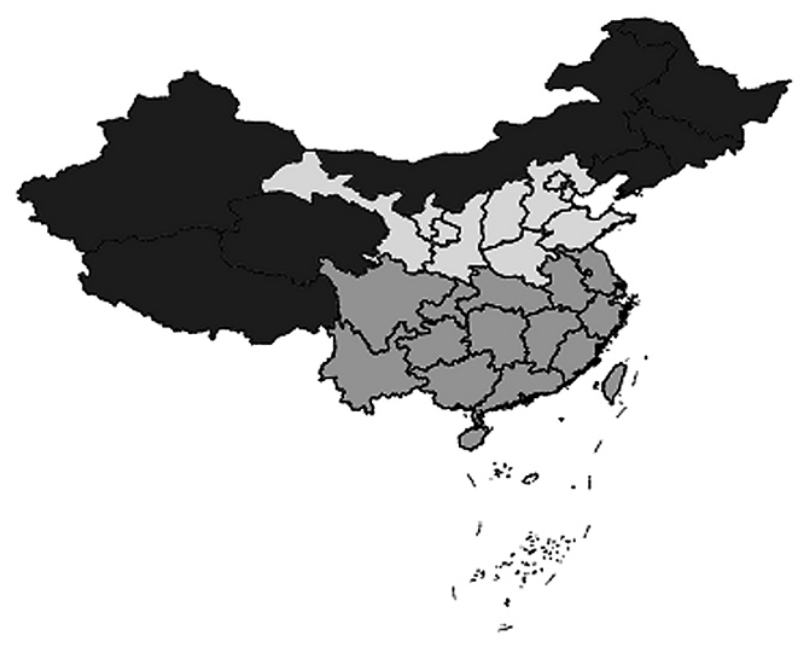

Pastoral Zone $\square$ Wheat Zone $\square$ Rice Zone

\section{Nomadic migration and conflicts between pastoralists and agriculturalists}

Resource scarcity includes reductions in the quantity or quality of resources; this scarcity will not only shrink the whole pie for the society, but also decrease the slices for each individual (HomerDixon 1994). Under the impacts of climate change, degradation of grassland will definitely increase the difficulty of making a living for pastoral societies. In addition, the relatively limited food choice further increases their vulnerabilities, because more diversity in food sources increases the capacity to maintain social stability (Homer-Dixon 1999). To escape from the harsh environment and search for a comfortable setting, nomadic minorities preferred migration as a feasible method of adaptation to climate change in historical China and consequently were regarded as the threat by Han Chinese (Fang and Liu 1992). Migration has been a major resource for human survival, adaptation, and growth across the centuries and millennia (Marsella and Ring 2003). However, mass migration to an occupied territory often implies warfare, which is a means for states to acquire or maintain desired areas of settlement (Reiter 2003). Hence, the special dynamics of a nomadic society and climatic/environmental pressures created tensions and violence (Baxter 1993, 2001).

However, Fang and Liu (1992) only discussed southward, including southwestward and southeastward, nomadic migration. Based on the patterns of rainfall and temperature distribution in pastoral China, isohyets and isotherm lines are parallel to latitude (Zhao 1986, Ren 1999). Therefore, by migrating only southward, nomadic minorities could reach a wetter and warmer place for survival if the climate deteriorated. However, a research gap that deserves attention is the study of northward migration, including northwestward and northeastward, under climate change. Therefore, we divided the records of nomadic migration into two directions: southward, including southwestward and southeastward, and northward, including 
northwestward and northeastward. A total of 651 records on southward nomadic migration and 243 records on northward migration were collected. A total of 34 records on nomadic migration with a straight eastward/westward direction were collected, and these data were excluded from the analysis of comparison on northward/southward migration in this section. Southward nomadic migration accounted for $72.8 \%$ of the total proportion. Correlation analysis (Table 4) and GCA (Table 5; Tables A4 and A5 in Appendix 1) also indicated that according to GCA, precipitation was the cause of northward/southward nomadic migration in historical China over the long term and on a large spatial scale.

Table 4. Correlation analysis of precipitation and northward/ southward migration.

\begin{tabular}{lcc}
\hline \hline & $\begin{array}{c}\text { Northward } \\
\text { migration }\end{array}$ & $\begin{array}{c}\text { Southward } \\
\text { migration }\end{array}$ \\
\hline Precipitation & -0.269 & -0.191 \\
P value & $<0.01$ & $<0.01$ \\
\hline
\end{tabular}

Table 5. Granger causality analysis of precipitation and northward/southward migration.

\begin{tabular}{lcc}
\hline \hline Null hypothesis & $\begin{array}{c}\text { F- } \\
\text { Statistic }\end{array}$ & Prob. \\
\hline $\begin{array}{l}\text { Precipitation does not (Granger) cause } \\
\text { northward migration. }\end{array}$ & 17.707 & $\mathrm{p}<0.01$ \\
$\begin{array}{l}\text { Precipitation does not (Granger) cause } \\
\text { southward migration. }\end{array}$ & 24.665 & $\mathrm{p}<0.01$ \\
\hline
\end{tabular}

Notably, besides the correlation analysis results in Table 4, northward nomadic migration (Fig. 3C) was also negatively related to precipitation (Fig. 3A). Northward nomadic migration peaked during droughts such as those from AD 300 to AD 450, a period also called the Five Barbarian Chaos, and from AD 1150 to AD 1300, the period of the Mongolian invasions. In historical China, nomadic minorities moved southward (Fig. 3B) in response to climate change, which usually caused armed conflicts between pastoral minorities and Han people. Furthermore, during the southward invasion, nomadic minorities always forced the Han people to move with them back to pastoral China from agricultural China (wheat-zone China and rice-zone China; Fig. 2; Ge 1991, 1997). Most of the Han people were sold as slaves. Therefore, the peak of northward nomadic migration was accompanied by the southward invasion of pastoralists because of climate change in historical China. Northward nomadic migration inevitably caused battles with agriculturalists (Fig. 3E) during slave robbery. In summary, nomadic migrations could have led to conflicts with agriculturalists.

Based on the above research, pairwise GCA was performed (Table 3) to systematically verify the relationship of nomadic migration to conflicts between pastoralists and agriculturalists. In Table 3, the null hypothesis that nomadic migration does not, according to GCA, cause conflict was rejected at the significance level of
Fig. 3. A) Precipitation anomaly (mm), 220 BC to AD 1910; B)

Southward nomadic migration, 220 BC to AD 1910; C)

Northward nomadic migration, 220 BC to AD 1910; D)

Nomadic migration, 220 BC to AD 1910; and E) Conflicts between pastoralists and agriculturalists, $200 \mathrm{BC}$ to AD 1910.
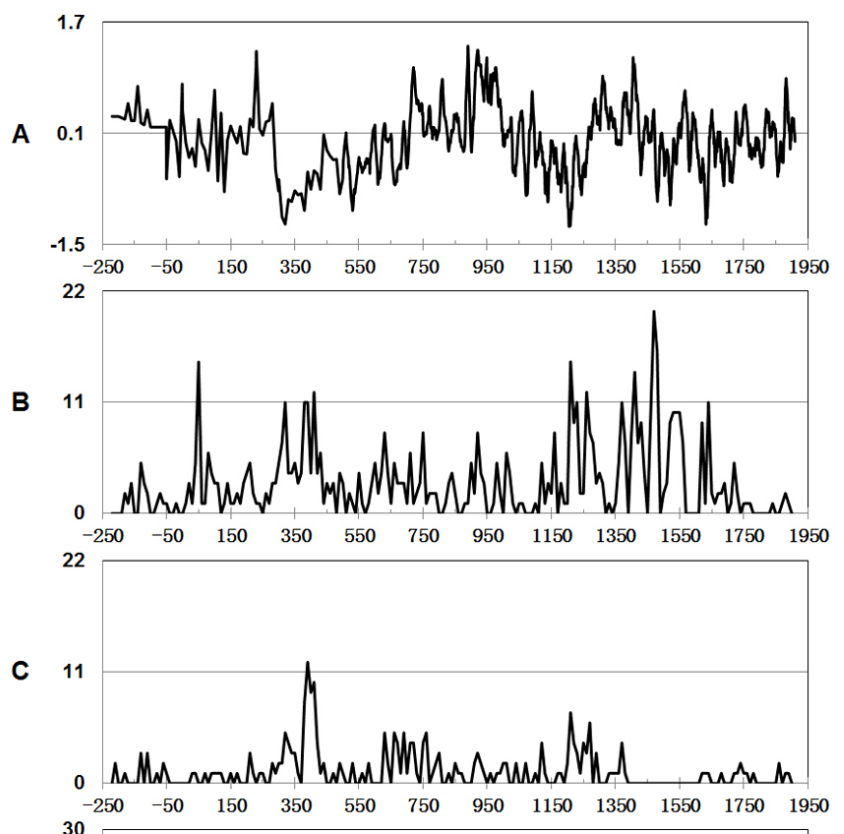

D
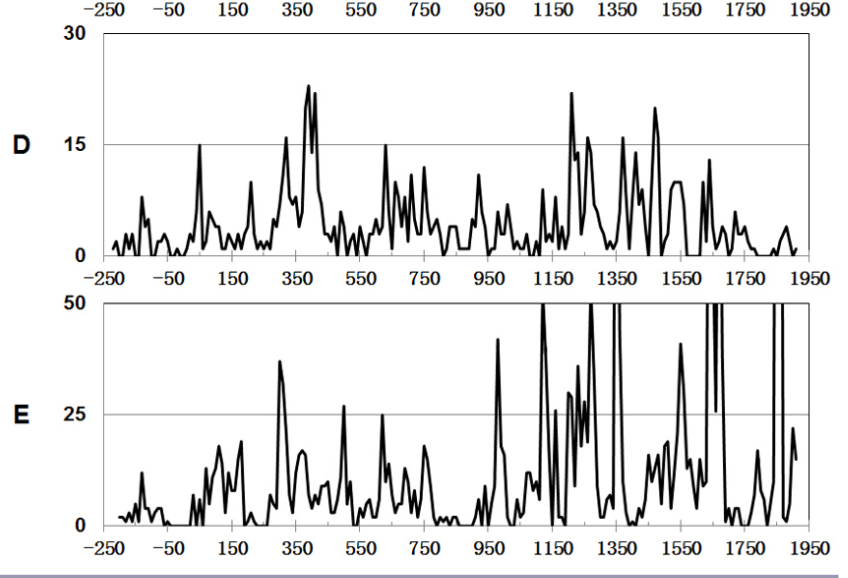

0.1 , but the null hypothesis that conflict does not, according to GCA, cause nomadic migration cannot be rejected at the level of 0.1 . Such results show that nomadic migration was the cause of conflicts between pastoralists and agriculturalists, but the opposite was not true. The conflicts between pastoralists and agriculturalists were results of nomadic migration over the long term, as shown by the quantitative results. To sum up, in previous societies, the influence of humans on climatic conditions was not as great as that in modern times. Therefore, the causal pathway of climate change $\rightarrow$ nomadic migration $\rightarrow$ conflicts between pastoralists and agriculturalists is not only theoretically sound but also statistically proven.

Most economic and social migration models are specific cases of the generalized Push-Pull model (Gary and Larkin 2008). The Push-Pull model uncovers the momentum behind human 
movement, which indicates that the migration arises from the push of discontent and adversity, as well as the pull of new possibilities and rewards (Marsella and Ring 2003). Results of the statistical analysis imply that climate change increased nomadic migration in historical China. Therefore, the push effect of climate change, especially drought, was the main reason for nomadic migration during the whole study period. In response to climate-induced ecological deterioration, pastoralists under strong push forces had to migrate to look for a place with enough water and warmth. Meanwhile, nomadic migration records indicate that southward nomadic migration rather than northward migration dominated most of the migration during the study period. The climate in South China is wetter and warmer than that in North China. Hence, the humid and mild climatic conditions in South China were the pull force for nomadic minorities.

Notably, nomadic migration more likely happened under climate change in the long term. Although the pull force always exists because of the Chinese physical geography, only an additional push force could result in southward nomadic migration. The push force was the last straw, given the vulnerabilities to climate change in pastoral China. The wetter and warmer climate as the pull force from South China controlled the nomadic migration directions in the long term under climate change. Based on our study of nomadic migration, the push and pull forces are not always equally important in the Push-Pull model. In summary, this study used the Push-Pull model for the first time to theoretically explain how climate change in the long term affected nomadic migration in historical China.

If the climate changed, especially if drought occurred, most nomadic people preferred to migrate southward, which was the long-term trend under the effects of both push and pull factors. Then, conflicts occurred between pastoralists and agriculturalists. Because the casual pathway climate change $\rightarrow$ nomadic migration $\rightarrow$ conflicts between pastoralists and agriculturalists is based on ancient Chinese history, the direct link between historical climate change and violent conflict was further tested. The result was also significant at the level of 0.1 (Table 6; Tables A6 and A7 in Appendix 1), which is consistent with the previous quantitative analysis on humidity and violent invasions of nomadic people (Bai and Kung 2011).

Table 6. Granger causality analysis of precipitation and conflict numbers.

\begin{tabular}{lcc}
\hline \hline Null hypothesis & $\begin{array}{c}\text { F- } \\
\text { Statistic }\end{array}$ & Prob. \\
\hline $\begin{array}{l}\text { Precipitation does not (Granger) cause } \\
\text { conflict number. }\end{array}$ & 1.474 & $\mathrm{p}<0.1$ \\
\hline
\end{tabular}

Currently, there are still countries or regions with the same development level as preindustrial China. Therefore, modern climate change could increase the migration rate, especially in these poor areas (Malcolm et al. 2002). The climate change could lead to the land in such underdeveloped regions being less able to support human life. There are already cases of mass migration, for example, in northern Ethiopia, that were caused by negative climate change (Meze-Hausken 2000). Our study on the causes of migration is timely because it will help facilitate further research into how people adapt to natural environments (Rouse 1986).

In addition, climate-induced migration can cause conflict (Hsiang et al. 2013), and this study on historical China has provided the quantitative evidence for this causal relationship. Note, however, that climate-induced environmental scarcity does not necessarily cause the conflicts; it is only one important indicator to consider under the political and economic systems (Homer-Dixon 1999). Furthermore, the study only quantitatively proved the reliability of the casual pathway climate change $\rightarrow$ nomadic migration $\rightarrow$ conflicts between pastoralists and agriculturalists on a long-term temporal scale. We anticipate that nowadays climate change and its related consequences will be sustained for a long period, based on the latest scientific research (IPCC 2013). Therefore, our study has implications for modern society under the continuous influences of long-term climate change.

\section{CONCLUSION}

This study has quantitatively justified the casual pathway climate change $\rightarrow$ nomadic migration $\rightarrow$ conflicts between pastoralists and agriculturalists by analyzing the climatic impact on nomadic migration throughout the entire history of imperial China. In the long term, precipitation is a more essential climatic factor than temperature in triggering nomadic migration. The study provides evidence that nomadic migration could be one direct cause of conflicts between pastoralists and agriculturalists. However, the northward migration of agriculturalists also should be given more attention in future studies.

Overall, the findings of this study do not refute other theories about nomadic migration in historical China within other temporal and spatial scales. This study differs from its predecessors in terms of both the temporal scale and the hierarchies of reasoning, i.e., levels of quantitative association. Any complex system is determined by different factors in different spatial-temporal scales (O'Neill et al. 1989, Norton and Ulanowicz 1992). With a given spatial-temporal scale, several processes are more fundamental than the rest of the system (Tilly 1984). The causal pathway climate change $\rightarrow$ nomadic migration $\rightarrow$ conflicts between pastoralists and agriculturalists is valid only from a long-term perspective and on a large spatial scale in historical China. Moreover, this long-term causal relationship holds true only for the pastoral system, which directly interacts with the ecosystem (Pratt et al. 1997).

Responses to this article can be read online at: http://www.ecologyandsociety.org/issues/responses. $\mathrm{php} / 6528$

\section{Acknowledgments:}

Support for this work is generously provided by a Prestigious Fellowship from the Research Grants Council of the government of the Hong Kong SAR, an Innovation Fellowship from Fudan University of China, and Postdoctoral Fellowship Fund from the University of Hong Kong. 


\section{LITERATURE CITED}

Akaike, H. 1974. A new look at the statistical model identification. IEEE Transactions on Automatic Control 19(6):716-723. http:// dx.doi.org/10.1109/TAC.1974.1100705

Bai, Y., and J. K. Kung. 2011. Climate shocks and Sino-nomadic conflict. The Review of Economics and Statistics 93(3):970-981. http://dx.doi.org/10.1162/REST a 00106

Baxter, P. T. W. 1993. The "new" East African pastoralist: an overview. Pages 143-162 in J. Markakis, editor. Conflict and decline of pastoralism in the Horn of Africa. Palgrave Macmillan, Basingstoke, Hampshire, UK.

Baxter, P. T. W. 2001. Immediate problems: a view from a distance. Pages 235-246 in M. A. M. Salih, T. Dietz, and A. G. M. Ahmad, editors. African pastoralism: conflict, institutions and government. Pluto, London, UK.

Begzsuren, S., J. E. Ellis, D. S. Ojima, M. B. Coughenour, and T. Chuluun. 2004. Livestock responses to droughts and severe winter weather in the Gobi Three Beauty National Park, Mongolia. Journal of Arid Environments 59(4):785-796. http://dx.doi. org/10.1016/j.jaridenv.2004.02.001

Bokovenko, N. A. 2005. Migrations of early nomads of the Eurasian steppe in a context of climatic changes. Pages 21-33 in E. M. Scott, A. Y. Alekseev, and G. Zaitseva, editors. Impact of the environment on human migration in Eurasia. Volume 42. Springer Netherlands, Heidelberg, Germany. http://dx.doi. org/10.1007/1-4020-2656-0 3

Bunge, M. 2009. Causality and modern science. 4th edition. Transaction, Piscataway, New Jersey, USA.

Büntgen, U., W. Tegel, K. Nicolussi, M. McCormick, D. Frank, V. Trouet, J. O. Kaplan, F. Herzig, K.-U. Heussner, H. Wanner, J. Luterbacher, and J. Esper. 2011. 2500 years of European climate variability and human susceptibility. Science 331(6017):578-582. http://dx.doi.org/10.1126/science.1197175

Butlin, R. A. 1993. Historical geography: through the gates of space and time. Edward Arnold, London, UK.

Chen, J. Q. 1987. An approach to the data processing of historical climate materials on the basis of floods and droughts of Tai Hu Basin [Translated from the Chinese]. Acta Geographica Sinica 42 (3):231-242.

Dayem, K. E., P. Molnar, D. S. Battisti, and G. H. Roe. 2010. Lessons learned from oxygen isotopes in modern precipitation applied to interpretation of speleothem records of paleoclimate from eastern Asia. Earth and Planetary Science Letters 295 (1-2):219-230. http://dx.doi.org/10.1016/j.epsl.2010.04.003

Editorial Committee of Chinese Military History. 1985. The military history of China [Translated from the Chinese]. Volume 2. Jiefangjun Press, Beijing, China.

Fang, J. 1990. The impact of climatic change on Chinese migration in historical times: a reappraisal. Pages 96-105 in Z. Liu, L. Zhang, and P. Shi, editors. Global change and environmental evolution in China. Inner Mongolian Printing House of Science and Technology, Hohhot, China.
Fang, J.-Q. 1993. Lake evolution during the last 3000 years in China and its implications for environmental change. Quaternary Research 39(2):175-185. http://dx.doi.org/10.1006/qres.1993.1021

Fang, J.-Q., and G. Liu. 1992. Relationship between climatic change and the nomadic southward migrations in eastern Asia during historical times. Climatic Change 22(2):151-168. http://dx. doi.org/10.1007/BF00142964

Galloway, P. R. 1986. Long-term fluctuations in climate and population in the preindustrial era. Population and Development Review 12(1):1-24. http://dx.doi.org/10.2307/1973349

Galvin, K. A. 2009. Transitions: pastoralists living with change. Annual Review of Anthropology 38:185-198. http://dx.doi. org/10.1146/annurev-anthro-091908-164442

Gary, L. P., and R. P. Larkin. 2008. Population geography: problems, concepts, and prospects. Ninth edition. Kendall Hunt, Dubuque, Iowa, USA.

Ge, J. 1991. Zhong guo ren kou fa zhan shi [The history of Chinese population growth]. Fujian People's Publishing House, Fuzhou, China.

Ge, J., S. Wu, and S. Cao. 1997. The history of migration in China [Translated from the Chinese]. Fujian People's Publishing House, Fu Jian, China.

Granger, C. W. J. 1988. Some recent developments in a concept of causality. Journal of Econometrics 39(1-2):199-211. http://dx. doi.org/10.1016/0304-4076(88)90045-0

Homer-Dixon, T. F. 1994. Environmental scarcities and violent conflict: evidence from cases. International Security 19(1):5-40. http://dx.doi.org/10.2307/2539147

Homer-Dixon, T. F. 1999. Environment, scarcity, and violence. Princeton University Press, Princeton, New Jersey, USA. http:// dx.doi.org/10.2307/2539147

Hsiang, S. M., M. Burke, and E. Miguel. 2013. Quantifying the influence of climate on human conflict. Science 341(6151). http:// dx.doi.org/10.1126/science. 1235367

Hu, H. 1983. Essays on China's populaiton distribution. East Normal University of China, Shanghai, China.

Hui, D., J. Wei-Feng, C. Yi-Yong, and S. Shi-Guang. 2013. The temporal and spatial distribution of dust storms on the North China Plain, AD 1464-1913. The Holocene 23(5):625-634. http:// dx.doi.org/10.1177/0959683612467479

Huq, S., H. Reid, M. Konate, A. Rahman, Y. Sokona, and F. Crick. 2004. Mainstreaming adaptation to climate change in Least Developed Countries (LDCs). Climate Policy 4(1):25-43. http://dx.doi.org/10.3763/cpol.2004.0404

Hussein, K., J. Sumberg, and D. Seddon. 1999. Increasing violent conflict between herders and farmers in Africa: claims and evidence. Development Policy Review 17(4):397-418. http://dx.doi. org/10.1111/1467-7679.00094

Intergovernmental Panel on Climate Change (IPCC). 2007. Climate change 2007: impacts, adaptation and vulnerability. Contribution of working group II to the fourth assessment report 
of the Intergovernmental Panel on Climate Change. M. L. Parry, O. F. Canziani, J. P. Palutikof, P. J. van der Linden, and C. E. Hanson, editors. Cambridge University Press, Cambridge, UK.

Intergovernmental Panel on Climate Change (IPCC). 2013. Climate change 2013: the physical science basis, in IPCC working group I contribution to IPCC 5th assessment report (AR5). T. Stocker, Q. Dahe, and G.-K. Plattner, editors. Intergovernmental Panel on Climate Change, Stockholm, Sweden.

Keay, J. 2008. China: a history. HarperPress, London, UK.

Lee, H. F., and D. D. Zhang. 2013. A tale of two population crises in recent Chinese history. Climatic Change 116(2):285-308. http:// dx.doi.org/10.1007/s10584-012-0490-9

Li, K. 2007. The formation and development of nomadic distributions in historical China [Translated from the Chinese]. Journal of Southwest University for Nationalities (Humanities and Social Science) 193:26-31.

MacDonald, K. I. 1998. Push and shove: spatial history and the construction of a portering economy in northern Pakistan. Comparative Studies in Society and History 40(2):287-317. http:// dx.doi.org/10.1017/S0010417598001091

Malcolm, J. R., A. Markham, R. P. Neilson, and M. Garaci. 2002. Estimated migration rates under scenarios of global climate change. Journal of Biogeography 29(7):835-849. http://dx.doi. org/10.1046/j.1365-2699.2002.00702.x

Marsella, A. J., and E. Ring. 2003. Human migration and immigration: an overview. Pages 3-22 in L. L. Adler and U. P. Gielen, editors. Migration: immigration and emigration in international perspective. Praeger, Westport, Connecticut, USA.

Meier, P., D. Bond, and J. Bond. 2007. Environmental influences on pastoral conflict in the Horn of Africa. Political Geography 26 (6):716-735. http://dx.doi.org/10.1016/j.polgeo.2007.06.001

Meze-Hausken, E. 2000. Migration caused by climate change: how vulnerable are people in dryland areas? Mitigation and Adaptation Strategies for Global Change 5(4):379-406. http://dx. doi.org/10.1023/A:1026570529614

Norton, B. G., and R. E. Ulanowicz. 1992. Scale and biodiversity policy: a hierarchical approach. Ambio 21:244-249.

O’Neill, R. V., A. R. Johnson, and A. W. King. 1989. A hierarchical framework for the analysis of scale. Landscape Ecology 3(3-4):193-205. http://dx.doi.org/10.1007/BF00131538

Pei, Q., D. D. Zhang, H. F. Lee, and G. Li. 2014. Climate change and macro-economic cycles in pre-industrial Europe. PLoS ONE 9(2):e88155. http://dx.doi.org/10.1371/journal.pone.0088155

Pei, Q., D. D. Zhang, G. D. Li, and H. Lee. 2013. Short- and longterm impacts of climate variations on the agrarian economy in pre-industrial Europe. Climate Research 56(2):169-180. http://dx. doi.org/10.3354/cr01145

Pratt, D. J., F. Le Gall, and C. de Haan. 1997. Investing in pastoralism: sustainable natural resource use in arid Africa and the Middle East. World Bank, Washington, D.C., USA. http://dx.doi. org/10.1596/0-8213-3943-5
Qian, W. H., Q. Hu, Y. F. Zhu, and D.-K. Lee. 2003. Centennialscale dry-wet variations in East Asia. Climate Dynamics 21 (1):77-89. http://dx.doi.org/10.1007/s00382-003-0319-3

Reiter, D. 2003. Exploring the bargaining model of war. Perspectives on Politics 1(1):27-43. http://dx.doi.org/10.1017/ $\underline{\mathrm{S} 1537592703000033}$

Ren, M.-E. 1999. An outline of Chinese physical geography [Translated from the Chinese]. Third edition. Commercial Press, Beijing, China.

Roberts, J. M. 1997. A short history of the world. Oxford University Press, New York, New York, USA.

Rouse, I. 1986. Migrations in prehistory: inferring population movement from cultural remains. Yale University Press, New Haven, Connecticut, USA.

Russo, F. 2009. Causality and causal modelling in the social sciences: measuring variations. Springer, Dordrecht, The Netherlands. http://dx.doi.org/10.1007/978-1-4020-8817-9

Saunders, P. J. 1988. Causality of U.S. agricultural prices and the money supply: further empirical evidence. American Journal of Agricultural Economics 70(3):588-596. http://dx.doi.org/10.2307/1241497

Sayre, N. F. 2005. Ecological and geographical scale: parallels and potential for integration. Progress in Human Geography 29 (3):276-290. http://dx.doi.org/10.1191/0309132505ph546oa

Sternberg, T. 2008. Environmental challenges in Mongolia's dryland pastoral landscape. Journal of Arid Environments 72 (7):1294-1304. http://dx.doi.org/10.1016/j.jaridenv.2007.12.016

Tan, M., T. Liu, J. Hou, X. Qin, H. Zhang, and T. Li. 2003. Cyclic rapid warming on centennial-scale revealed by a 2650-year stalagmite record of warm season temperature. Geophysical Research Letters 30(12):1617. http://dx.doi.org/10.1029/2003GL017352

Thornton, J. 2001. Population growth and economic growth: long-run evidence from Latin America. Southern Economic Journal 68(2):464-468. http://dx.doi.org/10.2307/1061606

Tilly, C. 1984. Big structures, large processes, huge comparisons. Russell Sage Foundation, New York, New York, USA.

Yang, B., A. Braeuning, K. R. Johnson, and S. Yafeng. 2002. General characteristics of temperature variation in China during the last two millennia. Geophysical Research Letters 29(9):38-138-4. http://dx.doi.org/10.1029/2001GL014485

Yi, L., H. Yu, J. Ge, Z. Lai, X. Xu, L. Qin, and S. Peng. 2012. Reconstructions of annual summer precipitation and temperature in north-central China since 1470 AD based on drought/flood index and tree-ring records. Climatic Change 110 (1-2):469-498. http://dx.doi.org/10.1007/s10584-011-0052-6

Yu, Y. 1998. Comment on the history of migration in China with major reference of dynasties of Liao, Song, Jing, Yuan [Translated from the Chinese]. The Zhe Jiang Academic Journal $1: 116,125-127$.

Zhang, D. 1984. Preliminary analysis of dust storm and its associated weather in the historical periods of China. Scientia Sinica 3:278-288. 
Zhang, D., C. Jim, C. Lin, Y. He, and F. Lee. 2005. Climate change, social unrest and dynastic transition in ancient China. Chinese Science Bulletin 50(2):137-144. http://dx.doi.org/10.1007/BF02897517

Zhang, D. D., H. F. Lee, C. Wang, B. Li, Q. Pei, J. Zhang, and Y. An. 2011a. The causality analysis of climate change and largescale human crisis. Proceedings of the National Academy of Sciences of the United States of America 108(42):17296-17301. http://dx.doi.org/10.1073/pnas.1104268108

Zhang, D. D., H. F. Lee, C. Wang, B. Li, J. Zhang, Q. Pei, and J. Chen. 2011 b. Climate change and large-scale human population collapses in the pre-industrial era. Global Ecology and Biogeography 20(4):520-531. http://dx.doi.org/10.1111/ j.1466-8238.2010.00625.x

Zhang, D. E. 1998. Paleoenvironmental records from Chinese historical documents. Advance in Earth Sciences 13:273-277.

Zhao, S. 1986. Physical geography of China. Science Press, John Wiley \& Sons, Beijing, China. 


\section{Appendix 1.}

\section{Precipitation Reconstruction}

In order to guarantee the reliability of our reconstructed precipitation, we used 21 documentary-based single-proxy hydro-climate reconstructions (annual resolution) were synthesized from 13 published references, of which the data length is greater than 500 years to guarantee the reliability of reconstruction. By adopting the documentary-based, we can obtain relatively pure information on precipitation change. These documentary-based single-proxy hydro-climate reconstructions cover all the regions in China as shown in Table A1.

In addition, the study aims to uncover the relationship between climate change and nomadic migration in the long term. Therefore, the data length of proxies should be greater than 500 years. However, these 21 data series still have different data length. Following current practices in the paleo-climate reconstruction, a same interval of mean average on the overlapping periods is set in order to make all the series with different data length comparable in time (Mann et al. 2008; Marcott et al. 2013). In our study, the overlapping period is 1200-1900 AD. Therefore, based on this overlapping period of 1200-1900 AD, we normalized all the data series for reconstruction.

In China, there are seven natural divisions which are identified by similar moisture condition, soil and vegetation which depend on climate, landscape, geological history within their borders (Zhao 1986). Here is the Seven natural divisions of China (Zhao 1986):

1. East Asian Monsoon China

1.1 Northeastern China (NE)

1.2 Northern China $(\mathrm{N})$

1.3 Central and Southern China (CS)

1.4 Southern China (S)

2. Northwestern Arid China

2.1 Inner Mongolia (IM)

2.2 Northwestern China (NW)

3. Qinghai-Tibetan Frigid Plateau

Qinghai-Tibetan Plateau (QT) 
Table A1 Data source for precipitation anomaly reconstruction

\begin{tabular}{|l|l|l|l|l|l|}
\hline & Data type & Time span & $\begin{array}{l}\text { Spatial coverage } \\
\text { of } \\
\text { Divisions }\end{array}$ & $\begin{array}{l}\text { Resoluti } \\
\text { on }\end{array}$ & Reference \\
\hline 1 & $\begin{array}{l}\text { Historical flood \& } \\
\text { drought records }\end{array}$ & AD 1120-1980 & CS & Decadal & Chen (1987) \\
\hline 2 & $\begin{array}{l}\text { Historical records of } \\
\text { lake surface area } \\
\text { variations }\end{array}$ & 1000 BC-AD 1989 & $\begin{array}{l}\text { CS+IM+N+NW+ } \\
\text { QT }\end{array}$ & Decadal & Fang (1993) \\
\hline 3 & $\begin{array}{l}\text { Historical flood \& } \\
\text { drought records }\end{array}$ & AD 230-1919 & CS+IM+N+NW & $\begin{array}{l}\text { Half-dec } \\
\text { adal }\end{array}$ & $\begin{array}{l}\text { Gong \& Hameed } \\
\text { (1991) }\end{array}$ \\
\hline 4 & $\begin{array}{l}\text { Historical flood \& } \\
\text { drought records }\end{array}$ & AD 1000-1950 & CS & Annual & Jiang et al. (2005) \\
\hline 5 & $\begin{array}{l}\text { Historical flood \& } \\
\text { drought records }\end{array}$ & AD 952-1997 & IM+N+CS+S & Annual & Qian et al. (2003) \\
\hline 6 & $\begin{array}{l}\text { Historical flood \& } \\
\text { drought records }\end{array}$ & AD 960-2000 & N+QT & Decadal & Tan et al. (2008) \\
\hline 7 & $\begin{array}{l}\text { Historical flood \& } \\
\text { drought records }\end{array}$ & AD 1-2000 & N+QT & Decadal & Tan et al. (2010) \\
\hline 8 & $\begin{array}{l}\text { Historical flood \& } \\
\text { drought records }\end{array}$ & AD 1-1979 & CS+N & Decadal & Yan et al.(1993) \\
\hline 9 & $\begin{array}{l}\text { Historical records of } \\
\text { Yellow River floods }\end{array}$ & 206 BC-AD 1938 & N & Decadal & $\begin{array}{l}\text { Yellow Water Resources } \\
\text { Committee (1982) }\end{array}$ \\
\hline 10 & $\begin{array}{l}\text { Historical dust-storm } \\
\text { records }\end{array}$ & AD 300-1939 & $\begin{array}{l}\text { CS+IM+N+NE+N } \\
\text { W }\end{array}$ & Decadal & Zhang (1984) \\
\hline 11 & $\begin{array}{l}\text { Historical flood \& } \\
\text { drought records }\end{array}$ & AD 1-1996 & CS+N & Decadal & $\begin{array}{l}\text { Zhang et } \\
\text { (1997b) }\end{array}$ \\
\hline 12 & $\begin{array}{l}\text { Historical flood \& } \\
\text { drought records }\end{array}$ & AD 960-1992 & $\begin{array}{l}\text { Zhang et al. } \\
\text { (1997a) }\end{array}$ \\
\hline 13 & $\begin{array}{l}\text { Historical flood \& } \\
\text { drought records }\end{array}$ & AD 500-2000 & CS+IM+N+NE & $\begin{array}{l}\text { Zheng et al } \\
\text { 2006) }\end{array}$ \\
\hline
\end{tabular}

Then, according to Table A1, the adopted documentary-based single-proxies have covered all seven natural divisions. Therefore, the reconstructed precipitation could well represent the China-wide precipitation. The spatial coverage of selected proxies in the study is reliable to show the precipitation change on the national scale in China. As mentioned, our aim is to study the relationship between climate change and nomadic migration in the long term. Therefore, all these normalized data series with spatially coverage of whole China is arithmetically averaged. In this way, we believe that the reconstruction could show general implications of past precipitation change on a long term scale.

For the temperature reconstruction series in the study, a reconstructed temperature series Yang et al's (2002) from multi-proxies (e.g., ice cores, lake sediment, and so on) throughout China is adopted. Temperature is reconstructed based on decadal resolution and covers AD 1-2000. The temperature reconstruction covers whole China, which has the same spatial scale to our reconstructed precipitation. Furthermore, Yang et al's temperature anomaly has been adopted as a reliable climatic indicator to study the relationship between climate change and social responses in historical China (Zhang et al. 2005; Lee \& Zhang 2013). 


\section{Granger Causality Analysis}

\section{Background}

In 2003, Sir Clive William John Granger was awarded with the Nobel Memorial Prize in Economic Sciences, in recognition to his contributions to the discoveries in the analysis of time series data which fundamentally changes economic study on the data of time. GCA is one of his brilliant achievements, which was emphasized by him when he was giving the prize speech (Granger 2003). Although GCA stems from economics, it has also been used commonly in the empirical studies of psychology (Sobel 1995), politics (Umez 1993), sociology (Walker \& Jackson 2007; Lin \& Ali 2009), biology (Fujita et al. 2010), medicine (Florin et al. 2008), and so on.

\section{Theoretical calculation process}

Granger's notion of causality is that ' $\ldots Y_{t}$ is causing $X_{t}$ if we are better able to predict $X_{t}$ using all available information than if the information apart from $Y_{t}$ had been used.'(Granger 1969). The GCA proposes a two-variable causal model with two stationary time series, $X_{t}$ and $Y_{t}$, with zero means:

$$
X_{t}=\sum_{j=1}^{m} a_{j} X_{t-j}+\sum_{j=1}^{m} b_{j} Y_{t-j}+\varepsilon_{t}
$$

where, $a$ and $b$ are the coefficients of the time series. $j$ is the data of the time series at time point $j$, and $m$ is the length of the time series which is set based on lag. $\varepsilon$ is the residue and $t$ is the time step.

The Augmented Dickey-Fuller (ADF) test approach controls higher-order correlation by adding lagged difference terms of the dependent variable $Y$ to the right-hand side of the regression, which can be written as the following equation (Agung 2009):

$$
D Y_{t}=\mu+\delta Y_{t-1}+\beta_{1} D Y_{t-1}+\beta_{2} D Y_{t-2}+\ldots+\beta_{p} D Y_{t-p}+\varepsilon_{t}
$$

where

$$
D Y_{t}=Y_{t}-Y_{t-1}
$$

The null hypothesis of the series $\left\{Y_{t}\right\}$ has a unit root, that is, $H_{0}: \delta=0$.

where, $\beta, \delta$ is the coefficient of the time series. $p$ is the data of the time series at time point $p$. $D$ means the differencing. $\varepsilon$ is the residue and $t$ is the time step.

The maximum lag in ADF Test can be chosen based on the following statistical formula (Hayashi 2000), which is also adopted by EViews as a default:

$$
\operatorname{Lag}_{\text {Max }}=\operatorname{int}\left[12 \times\left(\frac{T}{100}\right)^{0.25}\right]
$$


where $T$ is sample size and int means integer.

After applying the ADF test on the stationarity status of each data series, the lag length should be selected for the GCA. In the model, the lags of $X_{t}$ and $Y_{t}$ are set equally. Given that the $t$ or $F$ statistic is only a function, it depends on the correlation between the two variables and the set of conditioning variables. If the lag is set the same, then the same conditioning variables can be included (Kirchgässner \& Wolters 2007). Akaike's information criterion (AIC) is adopted to determine the appropriate lag length (Akaike 1974) as the statistical criteria.:

$$
\operatorname{AIC}(m)=2 m-2 \ln (L) \quad 1 \leq m \leq m_{\max }
$$

where $L$ is the maximum likelihood achievable by the model, $m$ is the number of parameters of the model, and $N$ is the number of data points used in the fit. $m_{\max }$ is the maximum lag, which can be chosen based on statistical Formula A4. We obtain the $m$ for the AIC lag in the ADF test and then apply $m$ to set the lag in Formula S1 for the GCA.

\section{ADF Test Results and Lag Selections}

Table A2 Time lag in Granger causality analysis on "climate change $\rightarrow$ nomadic migration $\rightarrow$ conflicts between pastoralists and agriculturalists"

\begin{tabular}{lc}
\hline Null hypothesis & Lag \\
\hline Precipitation does not (Granger) cause nomadic migration. & $1 \#$ \\
Temperature does not (Granger) cause nomadic migration. & $1 \#$ \\
Nomadic migration does not (Granger) cause conflict number. & $21^{\Delta}$ \\
Conflict number does not (Granger) cause nomadic migration. & $25^{\Delta}$ \\
\hline
\end{tabular}

Note: \# means the instantaneous lag for GCA. $\triangle$ means the AIC lag for GCA.

Table A3 Augmented Dickey-Fuller test in Granger causality analysis of "climate change $\rightarrow$ nomadic migration $\rightarrow$ conflicts between pastoralists and agriculturalists"

\begin{tabular}{lcl}
\hline Series & Prob. & Difference level \\
\hline Precipitation & $0.000^{\#}$ & No difference \\
Temperature & $0.001^{\#}$ & No difference \\
Nomadic migration & $0.000^{\#}$ & No difference \\
\hdashline Conflict number & $0.000^{\Delta}$ & No difference \\
Nomadic migration & $0.000^{\Delta}$ & No difference \\
\hline
\end{tabular}

Note: \# means the instantaneous lag for GCA. $\triangle$ means the AIC lag for GCA. 
Table A4 Time lag in Granger causality analysis of precipitation and northward/southward migration

\begin{tabular}{lc}
\hline Null hypothesis & Lag \\
\hline Precipitation does not (Granger) cause northward migration. \# & $1 \#$ \\
Precipitation does not (Granger) cause southward migration. \# & $1 \#$ \\
\hline
\end{tabular}

Note: \# means the instantaneous lag for GCA.

Table A5 Augmented Dickey-Fuller test in Granger causality analysis of precipitation and northward/southward migration

\begin{tabular}{lcl}
\hline Series & Prob. & Difference level \\
\hline Precipitation & $0.000^{\#}$ & No difference \\
Northward migration & $0.000^{\#}$ & No difference \\
Southward migration & $0.000^{\#}$ & No difference \\
\hline
\end{tabular}

Note: \# means the instantaneous lag for GCA.

Table A6 Augmented Dickey-Fuller test in Granger causality analysis of precipitation and conflicts between pastoralists and agriculturalists

\begin{tabular}{lcl}
\hline Series & Prob. & Difference level \\
\hline Precipitation & 0.002 & No difference \\
Conflict number & 0.000 & No difference \\
\hline
\end{tabular}

Table A7 Time lag in Granger causality analysis of precipitation and northward/southward migration

\begin{tabular}{lc}
\hline Null hypothesis & Lag \\
\hline Precipitation does not (Granger) cause conflict number. & 21 \\
\hline
\end{tabular}




\section{References}

Agung I.G.N. (2009). Time Series Data Analysis Using Eviews. John Wiley \& Sons (Asia) Pte Ltd, Singapore.

Akaike H. (1974). A new look at the statistical model identification. IEEE Transactions on Automatic Control, 19, 716-723.

Chen J.Q. (1987). An approach to the data processing of historical climate materials on the basis of floods and droughts of Tai Hu Basin. Acta Geographica Sinica, 42, 231-42.

Fang J. (1993). Lake Evolution during the Last 3000 Years in China and Its Implications for Environmental Change. Quaternary Research, 39, 175-185.

Florin E., Reck C., Burghaus L., Lehrke R., Gross J., Sturm V., Fink G.R. \& Timmermann L. (2008). Ten Hertz thalamus stimulation increases tremor activity in the subthalamic nucleus in a patient with Parkinson's disease. Clinical Neurophysiology, 119, 2098-2103.

Fujita A., Severino P., Sato J. \& Miyano S. (2010). Granger Causality in Systems Biology: Modeling Gene Networks in Time Series Microarray Data Using Vector Autoregressive Models. In: Advances in Bioinformatics and Computational Biology (eds. Ferreira C, Miyano S \& Stadler P). Springer Berlin / Heidelberg, pp. 13-24.

Gong G. \& Hameed S. (1991). The variation of moisture conditions in China during the last 2000 years. International Journal of Climatology, 11, 271-283.

Granger C.W.J. (1969). Investigating Causal Relations by Econometric Models and Cross-spectral Methods. Econometrica, 37, 424-438.

Granger C.W.J. (2003). Time Series Analysis, Cointegration, and Applications. The American Economic Review, 94, 421-425.

Jiang T., Zhang Q., Blender R. \& Fraedrich K. (2005). Yangtze Delta floods and droughts of the last millennium:abrupt changes and long term memory. Theoretical and Applied Climatology, 82.

Kirchgässner G. \& Wolters J. (2007). Introduction to Modern Time Series Analysis. Springer, Verlag Berlin Heidelberg.

Lee H.F. \& Zhang D.D. (2013). A tale of two population crises in recent Chinese history. Climatic Change, 116, 285-308.

Lin E.S. \& Ali H.E. (2009). Military Spending and Inequality: Panel Granger Causality Test. Journal of Peace Research, 46, 671-685.

Mann M.E., Zhang Z., Hughes M.K., Bradley R.S., Miller S.K., Rutherford S. \& Ni F. (2008). Proxy-based reconstructions of hemispheric and global surface temperature variations over the past two millennia. Proceedings of the National Academy of Sciences, 105, 13252-13257.

Marcott S.A., Shakun J.D., Clark P.U. \& Mix A.C. (2013). A Reconstruction of Regional and Global Temperature for the Past 11,300 Years. Science, 339, 1198-1201.

Qian W., Hu Q., Zhu Y. \& Lee D.K. (2003). Centennial-scale dry-wet variations in East Asia. Climate Dynamics, 21, 77-89.

Sobel M.E. (1995). Causal Inference in the Social and Behavioral Sciences. In: Handbook of statistical modeling for the social and behavioral sciences (eds. Arminger G, Clogg CC \& Sobel ME). Plenum Press New York, p. 14.

Tan L., Cai Y. \& An Z. (2010). Precipitation variations of Longxi over the last 2000 years and the possible driving forces. Journal of Arid Land Resources and Environment, 24, 99-116.

Tan L., Cai Y., Yi L., An Z. \& Ai L. (2008). Precipitation variations of Longxi, northeast margin of Tibetan Plateau since AD 960 and their relationship with solar activity. Climate of the Past, 4, 
19-28.

Umez B. (1993). Has social mobilization caused political instability in Africa? A granger-causality test. The Review of Black Political Economy, 22, 33-54.

Walker D.M. \& Jackson J.D. (2007). Do Casinos Cause Economic Growth? American Journal of Economics and Sociology, 66, 593-607.

Yan Z., Li Z. \& Wang X. (1993). An analysis of decade-to-century-scale climatic jumps in history. Scientia Atmospherica Sinica, 17, 663-672.

Yang B., Braeuning A., Johnson K.R. \& Yafeng S. (2002). General characteristics of temperature variation in China during the last two millennia. Geophysical Research Letters, 29, 1324.

Yellow River Water Resources Committee (1982). Prospective Summarization of Yellow River Water Resources. Yellow River Water Resources Press, Beijing.

Zhang D. (1984). Preliminary analysis of dust storm and its associated weather in the historical periods of China. Scientia Sinica, 3, 278-288.

Zhang D., Jim C., Lin C., He Y. \& Lee F. (2005). Climate change, social unrest and dynastic transition in ancient China. Chinese Science Bulletin, 50, 137-144.

Zhang D., Liu C. \& Jiang J. (1997a). Reconstruction of six regional dry/wet series and their abrupt changes during the last 1000 years in East China. Quaternary Sciences, 1, 1-10.

Zhang P., Ge Q., Zhang S. \& Liu X. (1997b). The modes and abrupt changes of climate in China during recent 2000 years. Quaternary Sciences, 12-20.

Zhao S. (1986). Physical Geography of China. Science Press, John Wiley \& Sons, Beijing.

Zheng J., Wang W., Ge Q., Man Z. \& Zhang P. (2006). Precipitation variability and extreme events in Eastern China during the past 1500 years. Terrestrial Atmospheric and Oceanic Sciences, 17, 579-92. 